\title{
Achilles Tendon Rupture: Mechanisms of Injury, Principles of Rehabilitation and Return to Play
}

\author{
Domiziano Tarantino *, Stefano Palermi, Felice Sirico (1) and Bruno Corrado \\ Department of Public Health, University Federico II of Naples, 80131 Naples, Italy; \\ stefano.palermi@unina.it (S.P.); sirico.felice@gmail.com (F.S.); bruno.corrado@unina.it (B.C.) \\ * Correspondence: domiziano22@gmail.com; Tel.: +39-329-264-6135
}

Received: 16 November 2020; Accepted: 15 December 2020; Published: 17 December 2020

\begin{abstract}
The Achilles tendon is the thickest, strongest and largest tendon in the human body, but despite its size and tensile strength, it frequently gets injured. Achilles tendon ruptures (ATRs) mainly occur during sports activities, and their incidence has increased over the last few decades. Achilles tendon tears necessitate a prolonged recovery time, sometimes leaving long-term functional limitations. Treatment options include conservative treatment and surgical repair. There is no consensus on which is the best treatment for ATRs, and their management is still controversial. Limited scientific evidence is available for optimized rehabilitation regimen and on the course of recovery after ATRs. Furthermore, there are no universally accepted outcomes regarding the return to play (RTP) process. Therefore, the aim of this narrative review is to give an insight into the mechanism of injuries of an ATR, related principles of rehabilitation, and RTP.
\end{abstract}

Keywords: Achilles tendon; tendon rupture; rehabilitation; return to play

\section{Introduction}

The Achilles tendon, which is about $12-15 \mathrm{~cm}$ long and comprises both the gastrocnemius and the soleus tendons, is the thickest, strongest and largest tendon in the human body. It arises near the middle of the calf and rotates approximately 90 degrees laterally during its course to insert on the posterior aspect of the calcaneal tuberosity [1,2].

Despite its size and tensile strength, Achilles tendon is the most commonly injured tendon in the human body [3,4].

Achilles tendon ruptures (ATRs) occur mainly during sports activities, more frequently in middle-aged men, especially untrained and recreational athletes who play sports occasionally, even though ruptures can occur in younger people [5]. The incidence of ATRs has increased over the last several decades, probably as a result of widespread sports participation [6,7]. Patients with an ATR report sudden and severe pain in the acute phase, and, if left untreated, the injury results in worsened physical function [8].

Achilles tendon tears necessitate a prolonged recovery, leaving a $10 \%$ to $30 \%$ reduction in functional calf strength and endurance [4,9-14], despite increased muscle activity $[15,16]$. The injury produces long-term limitations $[9,15,17,18]$, and many patients fail to return to sports activities at the same level of performance as before injury [19].

The correct diagnosis of ATR may be missed in up to $25 \%$ of patients at initial presentation [20-22]. The diagnosis relies on clinical examination, and imaging techniques can be useful in providing additional clinical information. Patients with an ATR usually report a history of pain in the affected leg and the feeling that, at the time of injury, they had been kicked in the posterior aspect of the lower leg or complain of a popping or giving way sensation in their heel after pushing off $[23,24]$. On clinical examination, diffuse edema and bruising are usually present, and, unless the swelling is 
severe, a palpable gap may be felt along the course of the tendon, most frequently 2 to $6 \mathrm{~cm}$ proximal to the insertion of the tendon [25]. Inspection and palpation should be followed by other tests to confirm the diagnosis, such as the Simmonds (or Thompson) and Matles test and the O'Brien and Copeland tests [23]. Imaging, especially diagnostic ultrasound (that is generally considered the primary imaging method) and magnetic resonance imaging [26-28], plays only an adjunct role in the diagnosis and monitoring of ATRs, and it is recommended to rely primarily on clinical examination and evaluation, and to use imaging for ruling out other injuries [28].

After rupture, tendons heal forming scar tissue, and most will never regain the same collagen structure, composition, and organization of healthy tissue [29]. This can lead to a decrease in the mechanical properties of the tissue and increased potential for re-rupture [30].

There is no consensus on which is the best treatment for ATRs, and its management is still controversial. Treatment options include conservative treatment and surgical repair [31]. Since the optimal treatment for acute ATR is continuously debated, recent studies have proposed that the choice of either operative or non-operative treatment may not be as important as rehabilitation [32].

Return to play (RTP) is very important for all athletes who suffered from an ATR, but despite an increased interest in RTP in the last years, there is still a lack of objective criteria for the RTP [33].

The aim of this narrative review is to give an insight into the mechanism of injuries of an ATR, related principles of rehabilitation, and RTP.

\section{Mechanisms of Injury}

Acute ATR usually occurs in its midportion, $2-6 \mathrm{~cm}$ proximal from the insertion on the calcaneus. The poor vascularity in the main body of the Achilles tendon may play an important role in the pathogenesis of the rupture [34,35].

In general, there are usually no warning symptoms, and the injury frequently occurs with a distinct ankle trauma. The rupture is generally total; true partial ATRs are very rare [35].

Acute ATRs are classically produced by a single high-load impact (for example, an ATR associated with sudden or violent dorsiflexion of ankle or lunge) [29]. Moreover, an acceleration-deceleration mechanism has been reported in up to $90 \%$ of sports-related ATRs [29]. Sporting activity plays a major role in the development of problems with the Achilles tendon, especially when inappropriate training sessions are performed [23,36].

Achilles tendon injuries are common in football, tennis, badminton, and jumping, and have a prevalence in running athletes of $11 \%$. However, $1 / 3$ of patients with this pathology do not practice intensive physical activity [29].

Degenerative changes are the most common histological findings in spontaneous tendon ruptures (such as high vascularity, collagen disorganization and hypercellularity relatively close to the ruptured site) and may lead to reduced tensile strength and a predisposition to rupture $[29,37,38]$.

A reduction in the number and diameter of type I collagen fibers that account for $95 \%$ of Achilles tendon collagen $[39,40]$, replaced with larger type III fibers that are produced by ruptured Achilles tendon and that are less resistant to tensile forces [41], are also present [42].

In addition, there are several other factors which play a role in the pathogenesis of ATR, including: gastrocnemius-soleus dysfunction, sub-optimally conditioned musculotendinous unit, age, gender, changes in training pattern, poor technique, previous injuries, footwear, poor tendon vascularity, and various pathologic conditions, such as infectious diseases, neurologic conditions hyperthyroidism, renal insufficiency, diabetes, arteriosclerosis, inflammatory and autoimmune conditions, hyperuricemia, genetically determined collagen abnormalities, and high serum lipid concentration [36,43-49]. Drugs such as anabolic steroids and fluoroquinolones cause dysplasia of collagen fibrils, which decreases tendon tensile strength and increases the risk of ATR $[23,50]$. 


\section{Principles of Rehabilitation}

Because there is conclusive evidence that outcomes after surgical and non-surgical treatment of ATR are comparable and the optimal treatment is continuously debated [32,51,52], methods of rehabilitation are becoming increasingly significant $[32,53,54]$. Nevertheless, data on the course of the recovery after ATR are still limited, potentially resulting in suboptimal rehabilitation [4].

The lack of available data about psychosocial factors related to outcome, the RTP after ATR treatment and novel imaging techniques, is then reflected on a high rate of re-rupture and complications $[51,55,56]$, unpredictable recovery and RTP $[15,19,57,58]$.

Several patient-related (BMI, nutritional status, comorbidities and athletic status) and injury-related (delay in presentation, injury etiology, gap-size) factors have a possible influence on the recovery and final outcome [55,59-61].

Regarding the gap-size, two recent studies aimed to assess if the amount of gap between tendon ends could affect the patient-reported outcome following ATR treated with functional rehabilitation $[62,63]$.

Mubark et al. [62] measured the tendon gap with an ultrasound scan on the initial presentation, then patients were followed for a minimum of 1 year and assessed for Achilles Tendon Rupture Score (ATRS), plantarflexion strength, and re-rupture rate. They found that the outcome following nonoperative functional rehabilitation treatment of rupture Achilles tendon did not correlate with the size of the tendon gap, and the study did not show a statistically significant correlation between the tendon gap size and ATRS at 12 months [62].

Yassin et al. [63], on the contrary, stated that increasing tendon gap (especially if $>10 \mathrm{~mm}$ ), measured using dynamic ultrasound scanning, is associated with poorer patient-reported treatment outcome after ATR functional rehabilitation, as measured by ATRS.

Recent studies suggested that functional rehabilitation and early weightbearing should be preferred over traditional immobilization $[32,64,65]$.

The main findings of the described studies are summarized in Table 1. Systematic reviews have been excluded from this table.

A meta-analysis by Mark-Christensen et al. [32] involving 427 participants, with a total of 211 participants treated with functional rehabilitation and 216 treated with immobilization, showed that there were no statistically significant differences between groups, with a trend favoring functional rehabilitation seen regarding the examined outcomes (such as re-rupture rate, RTP, earlier return to work, increased patient satisfaction, etc).

Aufwerber et al. [66] demonstrated that an accelerated post-operative protocol with immediate loading and ankle motion resulted in better general health and vitality at 6 months, but no differences between the groups were found in the recovery of heel-rise function.

Early rehabilitation after open repair for patients with an ATR was found to be helpful for functional recovery and showed better results in the return to work and the Achilles functional score [67]. Superior outcomes following an accelerated functional rehabilitation protocol with immediate weightbearing in a functional brace, together with early mobilization, were also found after minimal invasive Achilles tendon repair [64]. 
Table 1. Post-treatment interventions and findings.

\begin{tabular}{|c|c|c|c|c|c|c|}
\hline Author & Year & Type of Study & No. of Patients & Treatment & Post-Treatment Intervention & Findings \\
\hline Aufwerber et al. [66] & 2020 & $\mathrm{RCT}$ & 149 (98 EFM, 51 IM) & Surgery & $\begin{array}{l}\text { EFM group: dynamic orthosis, WB } \\
\text { as tolerated; } \\
\text { - IM group: below-knee plaster } \\
\text { cast, NWB. }\end{array}$ & $\begin{array}{l}\text { Higher scores in general } \\
\text { health and vitality at } 6 \\
\text { months in the EFM group. }\end{array}$ \\
\hline Kim et al. [67] & 2017 & $\begin{array}{l}\text { Case control study } \\
\text { (therapeutic) }\end{array}$ & 56 (32 ER, 24 CR) & Surgery & $\begin{array}{l}\text { ER group: short leg splint, } \\
\text { tolerable WB at 2-week follow-up; } \\
\text { CR group: below-knee cast, } \\
\text { tolerable WB at 4-week follow-up. }\end{array}$ & $\begin{array}{l}\text { Better results regarding } \\
\text { return to work in the } \\
\text { ER group; } \\
\text { Better Achilles functional } \\
\text { score in the ER group. }\end{array}$ \\
\hline Costa et al. [68] & 2020 & $\mathrm{RCT}$ & $540(274 \mathrm{FB}, 266 \mathrm{IM})$ & Conservative & $\begin{array}{l}\text { - } \quad \text { FB group: FB with EWB; } \\
\text { - } \quad \text { IM group: plaster cast, EFM with } \\
\text { crutches, NWB on injured hindfoot. }\end{array}$ & $\begin{array}{l}\text { - Similar outcomes to } \\
\text { traditional plaster casting } \\
\text { with FB plus EWB; } \\
\text { - FB safe option for } \\
\text { non-operative treatment. }\end{array}$ \\
\hline Maempel et al. [69] & 2020 & $\mathrm{RCT}$ & $\begin{array}{l}140(69 \mathrm{FR}+\mathrm{EWB}, 71 \\
\text { IM) }\end{array}$ & Conservative & $\begin{array}{l}\text { - FR+EWB group: walking boot, } \\
\text { immediate FWB; } \\
\text { - } \quad \text { IM group: immobilizing cast, } \\
8 \text { weeks of NWB. }\end{array}$ & $\begin{array}{l}\text { - FR with EWB safe } \\
\text { alternative to } \\
\text { traditional IM; } \\
\text { Better early functional } \\
\text { outcomes with FR. }\end{array}$ \\
\hline Hutchinson et al. [70] & 2015 & $\begin{array}{l}\text { Descriptive case } \\
\text { series }\end{array}$ & $\begin{array}{l}273 \text { (SMART } \\
\text { programme) }\end{array}$ & $\begin{array}{c}\text { Surgery, } \\
\text { conservative }\end{array}$ & $\begin{array}{l}\text { - } \quad \text { SMART group: functional orthoses, } \\
\text { EWB, accelerated exercise regime. }\end{array}$ & $\begin{array}{ll}\text { - } & \text { Low re-rupture rate; } \\
\text { - } & \text { Satisfactory outcomes; } \\
\text { - } & \text { Reduced rate of } \\
\text { - } & \text { surgical intervention; } \\
\text { Reduced healthcare costs. }\end{array}$ \\
\hline
\end{tabular}


Table 1. Cont.

\begin{tabular}{|c|c|c|c|c|c|c|}
\hline Author & Year & Type of Study & No. of Patients & Treatment & Post-Treatment Intervention & Findings \\
\hline Aujla et al. [71] & 2019 & $\begin{array}{c}\text { Prospective } \\
\text { comparative study }\end{array}$ & 442 (LAMP protocol) & Conservative & $\begin{array}{l}\text { - LAMP group: 8-week functional } \\
\text { dynamic treatment, functional boot } \\
\text { with EWB. }\end{array}$ & $\begin{array}{l}\text { - } \quad \text { Less overall time in } \\
\text { the boot; } \\
\text { - } \quad \text { Low complication rates; } \\
\text { - } \quad \text { Similar patient } \\
\text { reported outcomes. }\end{array}$ \\
\hline Aufwerber et al. [72] & 2020 & Cohort study & 86 (55 EFM, 31 IM) & Surgery & $\begin{array}{l}\text { - } \quad \text { EFM group: dynamic } \\
\text { orthosis, FWB; } \\
\text { - } \quad \text { IM group: below-knee plaster } \\
\text { cast, NWB. }\end{array}$ & $\begin{array}{l}\text { - More elongation at early } \\
\text { healing with EFM, but it } \\
\text { subsides over time. }\end{array}$ \\
\hline Valkering et al. [73] & 2017 & $\mathrm{RCT}$ & 56 (27 FWB, 29 IM) & Surgery & $\begin{array}{l}\text { - FWB group: functional } \\
\text { mobilization, functional boot; } \\
\text { IM group: below-knee plaster } \\
\text { cast, NWB. }\end{array}$ & $\begin{array}{l}\text { Enhanced early healing } \\
\text { response with functional } \\
\text { WB in the FWB group; } \\
\text { Improved early ankle } \\
\text { range of motion without } \\
\text { risk of elongation in the } \\
\text { FWB group. }\end{array}$ \\
\hline
\end{tabular}

$\mathrm{RCT}=$ randomized controlled trial; $\mathrm{EFM}=$ early functional mobilization; $\mathrm{IM}=$ immobilization; $\mathrm{WB}=$ weightbearing; $\mathrm{NWB}=$ non-weightbearing; $\mathrm{ER}=$ early rehabilitation; $\mathrm{CR}=$ conventional rehabilitation; FB = functional bracing; EWB = early weightbearing; FR = functional rehabilitation; SMART = Swansea Morriston Achilles Rupture Treatment; LAMP = Leicester Achilles Management Protocol; FWB = full weightbearing. 
Early weightbearing in a functional brace was found to provide similar outcomes when compared with traditional plaster casting, resulting to be a safe alternative for patients receiving non-operative treatment of ATR, and to be associated with better early functional outcomes and lower costs $[68,69,74]$.

The concerns rose in the past referred to the risk of re-rupture following a functional rehabilitation protocol have been overcome due to new data that support it, which showed lower re-rupture rates when compared with non-weightbearing and casting [70,71,75]. The lowest re-rupture rates were found in strict functional rehabilitation protocols with full weightbearing in boot immediately at full equinus or at $30^{\circ}$ of plantar flexion [76].

Tendon lengthening is another significant problem, usually occurring after ATR [12], but few studies tested how early functional rehabilitation affects tendon elongation [72,77].

Valkering et al. [73] found that functional weightbearing mobilization improved early ankle range of motion without the risk of Achilles tendon elongation and without altering long-term functional outcomes.

A recent prospective cohort study by Aufwerber et al. [72] showed that early functional mobilization with immediate weightbearing and ankle motion, when compared with immobilization in a plaster cast for the first 2 weeks, resulted in more Achilles tendon elongation during the early healing period after surgery (i.e., at 2 weeks after surgery), but at 1 year there was no difference in elongation, also with a trend of less muscle atrophy with an accelerated rehabilitation protocol.

The rate of tendon repair after early mobilization seemed to be significantly improved if compared with continuous immobilization, and resulted in the improved orientation of collagen fibers, improved collagen synthesis, increased number and size of fibrils, increased tendon strength, vascularity, breaking strength, and reduced adhesions and scar formation [78-80].

Basic science research showed that mechanical stimulation improves tendon repair, which supports the idea that early mobilization and exercise following ATR may be beneficial [81,82].

Earlier research also showed that the loading of healing tendons leads to essential changes in the biologic process of tendon healing [73,83]. Moreover, early weightbearing could theoretically prevent muscle atrophy, stiffness, adhesions, and deep venous thrombosis (DVT), and has been associated with faster healing and stronger tendons because of improved vascularization and an improved immunologic response [84-86].

In any case, some authors found that early controlled ankle motion did not reduce the incidence of DVT when compared to immobilization [87]. In order to effectively minimize the risk of DVT, Aufwerber et al. [66] suggested that patients should be encouraged to load at least $50 \%$ of body weight on the injured leg 1 week after surgery.

Therefore, early mobilization and early functional rehabilitation after operative and non-operative treatment of ATRs has been advocated since they lead to new tendon formation and better ultimate functional outcomes, and do not increase post-operative complications [64,88-92].

There is limited available evidence for optimized rehabilitation regimen, and guidelines for initial rehabilitation are limited as well $[65,93]$.

Recently, the rehabilitation regimen after ATR has become more active, and it is characterized by partial or full weightbearing in the first 2 weeks after surgery, and active controlled mobilizations in the first few days after surgery [65].

A study by Frankewycz et al. [93] analyzed 243 protocols for operative and non-operative treatment for ATR provided by 204 orthopedic and trauma surgery institutions throughout Germany. Even if the majority of protocols allowed increased weightbearing over time, a huge variability in rehabilitation after ATR was found [93].

A post-operative protocol described by Maffulli et al. [94] let patients to be discharged the same day of the operation and allowed them to bear weight on the metatarsal heads of the operated leg using elbow crutches as tolerated. An orthopedic physiotherapist should instruct the patient to use crutches. At the time of discharge from the hospital after the operation, all patients were given an appointment for review 2 weeks post-operatively. At 2 weeks, the plaster was removed, and a 
commercially available removable walker was applied, with five wedges, each $1.2 \mathrm{~cm}$ thick, at the heel. Proprioception, active plantar flexion, inversion and eversion exercises were allowed against manual resistance provided by a physiotherapist. One heel wedge was removed every other week, and, at 6 weeks post-operatively, the patients were left free of the cast and referred to physiotherapy for active mobilization. At 10 or 12 weeks post-operatively, patients were assessed as to whether they were able to undertake more vigorous physiotherapy. Further follow-ups at 14 and 18 weeks were arranged. Patients were reviewed during the sixth post-operative month. They were then followed up at 3 months intervals and discharged 12 months after the operation, once they were able to perform at least five toe raises unaided on the operated leg and after they returned to their work or sport.

Patients usually return to their normal sports activity 6 months after the surgery. Time-based guidelines have suggested resumption of non-contact sports 16 weeks after injury and contact sports 20 weeks after injury, but these recommendations are not evidence based [95].

Furthermore, since strength recovery following operative repair of an ATR has been associated with increased ability to return to a previous level of play in patients with higher level athletic activity prior to injury, athletes who desire a return to high-level performance should be informed about the importance of regaining strength and guided toward effective rehabilitation efforts for this purpose [96].

\section{Return to Play}

RTP is crucial for all the athletes who suffered from an ATR. This kind of injury is significant and severely affects the ability of athletes to play at a high level [33]. However, the goal of surgeon and athlete alike is to try to minimize this impact [33]. Different studies have evaluated the rates of RTP in the last few years, showing how the interest in it has been exponentially growing up. There is still a lack of objective criteria for RTP, and the higher the level of sport, the higher the demands, and the pressure on medical professionals to get athletes back to play as quickly as possible [33].

Objective criteria should be used when possible. In the context of Achilles rupture, the Achilles tendon Total Rupture Score (ATRS) has been used widely as an outcome measure [33]. This score is a patient-reported outcome instrument consisting of 10 questions that demonstrate clinical utility for measuring outcomes after ATR [97]. Hansen et al. [98] found out that a patient's ATRS at 3 months after injury could predict the ability of RTP at 1 year.

The rate of RTP of each selected study is reported in Table 2.

Table 2. Rate of RTP.

\begin{tabular}{ccccc}
\hline Author & Year & No. of Patients & Type of Sport & Rate of RTP \\
\hline Zellers et al. [19] & 2016 & 6506 & ND & $80 \%$ \\
Johns et al. [99] & 2020 & 333 & Football, basketball, baseball, soccer & $76 \%$ \\
Trofa et al. [57] & 2017 & 62 & Basketball, football, baseball, hockey & $69.4 \%$ \\
Siu et al. [100] & 2020 & 12 & Basketball & $83.3 \%$ \\
Amin et al. [101] & 2013 & 18 & Basketball & $61 \%$ \\
Trofa et al. [102] & 2018 & 24 & Soccer & $70.8 \%$ \\
Lerch et al. [103] & 2020 & 89 & ND & $>70 \%$ \\
Grassi et al. [104] & 2020 & 118 & Soccer & $96 \%$ \\
\hline \multicolumn{7}{c}{ ND = not defined. }
\end{tabular}

A systematic review and meta-analysis by Zellers et al. [19] based on 85 studies that included a measure for determining RTP reported that the rate of RTP in all studies was $80 \%$, nearly the same rate of RTP $(76 \%)$ reported in a more recent systematic review by Johns et al. [99].

Trofa et al. [57] examined RTP and performance among professional athletes after AT repair and compared pre- versus post-operative functional outcomes of professional athletes from different major leagues in the United States. They stated that the $30.6 \%$ of the professional athletes included in the study with an isolated ATR treated surgically were unable to RTP. They also pointed out that the athletes who returned to play took part in fewer games, had less play time, and performed at a lower 
level than their preinjury status [57]. However, these functional deficits were seen only at 1 year after surgery compared with matched controls, such that players who return to play can expect to perform at a similar level with healthy controls 2 years post-operatively [57].

These data were later confirmed by Siu et al. [100], who stated that the professional examined basketball players with unilateral ATR reached their post-injury peak performance level at the second season back, and that the post-injury peak performance was significantly worse than the pre-injury level but was similar to matched non-injured players.

Amin et al. [101] followed 18 professional basketball players of the National Basketball Association (NBA) with Achilles tendon repair and took in account several variables (such as age, BMI, player position, etc) and the NBA player efficiency rating (PER) in order to assess the RTP and performance changes. They found that 7 players never returned to play an NBA game, whereas 11 players returned to play one season, with 8 of those players returning for more than two seasons [101]. The PER was reduced more in the first season than in the second season. Given these results, they concluded that the NBA players who returned to play after repair of complete ATRs showed a significant decrease in playing time and performance, with $39 \%$ of players never returning to play [101].

Another study by Trofa et al. [102] examined the RTP, playing time, and performance of professional soccer players of the Union of European Football Associations (UEFA) and Major League Soccer (MLS) following ATR. They found that the $70.8 \%$ of the selected soccer players were able to return to play, confirming that nearly the $30 \%$ of them $(29.2 \%)$ were unable to return to play, as reported in their other above-mentioned study [57]. In any case, the major difference between the two studies is that, while in the first study professional athletes reached the same pre-injury performance 2 years post-operatively [57], in the present study, soccer players were found to play fewer minutes 2 years post-operatively compared with their baseline as well as playing less at 1 and 2 years post-operatively compared with uninjured matched controls [102]. The reduction in playing time following an Achilles repair has significant implications for professional players and teams [102].

In a recent retrospective observational study by Lerch et al. [103], 5-year return to sport and subjective satisfaction, minimum 1-year functional outcomes, and complications in patients following non-operative treatment of ATR with early weightbearing rehabilitation were assessed. The results of the study highlighted that non-operative treatment for ATR reported good functional outcome and high patient satisfaction [103]. For patients with a high preinjury activity level (such as athletes involved in competitive sports), return to previous sporting level, assessed by the Tegner Activity Scale (TAS), was possible in $67 \%$ of the patients compared to $>90 \%$ of patients with low preinjury activity level (such as workers or people involved in recreational sports) [103].

Finally, a recent study by Grassi et al. [104] evaluated the RTP of 118 professional male soccer players of League 1 and League 2 following acute ATR and surgical repair identified through internet-based injury reports. Only soccer players with injuries who had at least 1 year of follow-up from the search date were included and those who competed for at least two seasons after returning to play, re-ruptures and number of matches played were reported. Of the 118 players, the $96 \%$ returned to unrestricted practice and then competition after an average time of 7 and 9 months, respectively [103]. However, $18 \%$ did not return to the same level of play within the two seasons following their return, and the $8 \%$ sustained a re-rupture within the first two seasons after RTP [104].

\section{Conclusions}

Trauma mechanisms that lead to an ATR are now well understood, classically occurring due to a single high-load impact or an acceleration-deceleration mechanism [1,29]. Degenerative changes are present in spontaneous tendon ruptures and may lead to a predisposition to ATR $[29,37,38]$.

There is conclusive evidence that outcomes after surgical and non-surgical treatment of ATR are comparable [51,52], and recent literature has indicated that functional rehabilitation without surgery can lead to comparable results (patient-reported outcomes and re-rupture) to surgery, without the risk 
of complications [105]. However, surgical intervention has been noted to provide improved strength compared with functional rehabilitation, and even if this might not be critical for most individuals, for elite athletes it could be career ending; therefore, surgical intervention was recommended for all elite athletes wishing to return to sport after ATR [106].

Methods of rehabilitation are becoming increasingly significant $[32,53,54]$, but there is still limited available evidence for optimized rehabilitation regimen, limited guidelines for the initial rehabilitation [65,93], and limited data on the course of the recovery after ATR and long-term outcomes of athletes [4]. Early weightbearing and early functional rehabilitation after operative and non-operative treatment of ATRs has been advocated since they lead to new tendon formation and better ultimate functional outcomes (such as return to work) $[67,77,88-92,107]$. Since there is not a universally accepted protocol of early rehabilitation and timing of weightbearing, further studies are needed in the future [92].

There are no universally accepted outcomes regarding the RTP among the selected studies. Some intrinsic and extrinsic factors could potentially affect the RTP. For example, BMI is a modifiable risk factor, which, when lowered, may be associated with less impairment in sports 1 year after an ATR [108].

The mean rate of athletes being unable to RTP among the above-mentioned studies was $29.7 \pm 6.738[19,57,101,102]$, and athletes who did not return to their previous level of sport was $25.5 \pm 7.5[103,104]$.

Even if the RTP could be satisfactory without any significant drop-off in performance upon return, for some athletes the ATR could appear to impact their chances of playing professionally in the future [109].

In accordance with the majority of the previously discussed articles, we can state that functional rehabilitation with early weightbearing after an ATR is superior to traditional immobilization. Moreover, more than $70 \%$ of athletes are able to return to play after an ATR.

Author Contributions: Conceptualization, D.T.; Validation, F.S. and B.C.; Writing-Original Draft Preparation, D.T. and S.P.; Writing-Review and Editing, S.P. and F.S.; Supervision, B.C. All authors have read and agreed to the published version of the manuscript.

Funding: This research received no external funding.

Conflicts of Interest: The authors declare no conflict of interest.

\section{References}

1. Maffulli, N.; Aicale, R.; Tarantino, D. Tendinopathy of the Achilles Tendon. In Ankle Joint Arthroscopy: A Step-By-Step Guide; Allegra, F., Cortese, F., Lijoi, F., Eds.; Springer: Cham, Switzerland, 2020; pp. $227-237$. [CrossRef]

2. Aicale, R.; Tarantino, D.; Maffulli, N. Non-Insertional Achilles Tendinopathy: State of the Art. In Sports Injury of The Foot and Ankle: A Focus on Advanced Surgical Techniques; Canata, G.L., d'Hooghe, P., Hunt, K.J., Kerkhoffs, G., Longo, U.G., Eds.; Springer: Berlin, Germany, 2019; pp. 359-367. [CrossRef]

3. Oda, H.; Sano, K.; Kunimasa, Y.; Komi, P.V.; Ishikawa, M. Neuromechanical Modulation of the Achilles Tendon During Bilateral Hopping in Patients with Unilateral Achilles Tendon Rupture, Over 1 Year After Surgical Repair. Sports Med. 2017, 47, 1221-1230. [CrossRef] [PubMed]

4. Dams, O.C.; Akker-Scheek, I.V.D.; Diercks, R.L.; Wendt, K.W.; Bosma, E.; Van Raaij, T.M.; Munzebrock, A.V.; Zijlstra, W.P.; Zwerver, J.; Reininga, I.H.F. The recovery after Achilles tendon rupture: A protocol for a multicenter prospective cohort study. BMC Musculoskelet. Disord. 2019, 20,1-8. [CrossRef] [PubMed]

5. Wertz, J.; Galli, M.; Borchers, J.R. Achilles Tendon Rupture: Risk Assessment for Aerial and Ground Athletes. Sports Health 2013, 5, 407-409. [CrossRef] [PubMed]

6. Maffulli, N.; Waterston, S.W.; Squair, J.; Reaper, J.; Douglas, A.S. Changing Incidence of Achilles Tendon Rupture in Scotland: A 15-Year Study. Clin. J. Sport Med. 1999, 9, 157-160. [CrossRef] [PubMed]

7. Lantto, I.; Heikkinen, J.; Flinkkilä, T.; Ohtonen, P.; Leppilahti, J. Epidemiology of Achilles tendon ruptures: Increasing incidence over a 33-year period. Scand. J. Med. Sci. Sports 2015, 25, e133-e138. [CrossRef] 
8. Bertelli, R.; Gaiani, L.; Palmonari, M. Neglected rupture of the Achilles tendon treated with a percutaneous technique. Foot Ankle Surg. 2009, 15, 169-173. [CrossRef]

9. Heikkinen, J.; Lantto, I.; Flinkkilä, T.; Ohtonen, P.; Pajala, A.; Siira, P.; Leppilahti, J. Augmented Compared with Nonaugmented Surgical Repair After Total Achilles Rupture: Results of a Prospective Randomized Trial with Thirteen or More Years of Follow-Up. J. Bone Jt. Surg. Am. 2016, 98, 85-92. [CrossRef]

10. Olsson, N.; Nilsson-Helander, K.; Karlsson, J.; Eriksson, B.I.; Thomée, R.; Faxén, E.; Silbernagel, K.G. Major functional deficits persist 2 years after acute Achilles tendon rupture. Knee Surg. Sports Traumatol. Arthrosc. 2011, 19, 1385-1393. [CrossRef]

11. Olsson, N.; Silbernagel, K.G.; Eriksson, B.I.; Sansone, M.; Brorsson, A.; Nilsson-Helander, K.; Karlsson, J. Stable Surgical Repair with Accelerated Rehabilitation versus Nonsurgical Treatment for Acute Achilles Tendon Ruptures: A Randomized Controlled Study. Am. J. Sports Med. 2013, 41, 2867-2876. [CrossRef]

12. Silbernagel, K.G.; Steele, R.; Manal, K. Deficits in Heel-Rise Height and Achilles Tendon Elongation Occur in Patients Recovering from an Achilles Tendon Rupture. Am. J. Sports Med. 2012, 40, 1564-1571. [CrossRef]

13. Willits, K.; Amendola, A.; Bryant, D.; Mohtadi, N.G.; Giffin, J.R.; Fowler, P.J.; Kean, C.O.; Kirkley, A. Operative versus Nonoperative Treatment of Acute Achilles Tendon Ruptures: A Multicenter Randomized Trial Using Accelerated Functional Rehabilitation. J. Bone Jt. Surg. Am. 2010, 92, 2767-2775. [CrossRef] [PubMed]

14. Bostick, G.P.; Jomha, N.M.; Suchak, A.A.; Beaupre, L.A. Factors Associated With Calf Muscle Endurance Recovery 1 Year After Achilles Tendon Rupture Repair. J. Orthop. Sports Phys. Ther. 2010, 40, 345-351. [CrossRef] [PubMed]

15. Horstmann, T.; Lukas, C.; Merk, J.; Brauner, T.; Mündermann, A. Deficits 10-Years after Achilles Tendon Repair. Int. J. Sports Med. 2012, 33, 474-479. [CrossRef] [PubMed]

16. Suydam, S.M.; Buchanan, T.S.; Manal, K.; Silbernagel, K.G. Compensatory muscle activation caused by tendon lengthening post-Achilles tendon rupture. Knee Surg. Sports Traumatol. Arthrosc. 2015, 23, 868-874. [CrossRef]

17. Lantto, I.; Heikkinen, J.; Flinkkila, T.; Ohtonen, P.; Kangas, J.; Siira, P.; Leppilahti, J. Early Functional Treatment versus Cast Immobilization in Tension after Achilles Rupture Repair: Results of a Prospective Randomized Trial with 10 or More Years of Follow-Up. Am. J. Sports Med. 2015, 43, 2302-2309. [CrossRef]

18. Mavrodontidis, A.; Lykissas, M.; Koulouvaris, P.; Kontogeorgakos, V.A.; Giannoulis, D.; Zalavras, C. Percutaneous Repair of Acute Achilles Tendon Rupture: A Functional Evaluation Study with a Minimum 10-Year Follow-up. Acta Orthop. Traumatol. Turc. 2015, 49, 661-667. [CrossRef]

19. Zellers, J.A.; Carmont, M.R.; Silbernagel, K.G. Return to play post-Achilles tendon rupture: A systematic review and meta-analysis of rate and measures of return to play. Br. J. Sports Med. 2016, 50, 1325-1332. [CrossRef]

20. Maffulli, N. Clinical tests in sports medicine: More on Achilles tendon. Br. J. Sports Med. 1996, $30,250$. [CrossRef]

21. Maffulli, N.; Aicale, R.; Tarantino, D. Autograft Reconstruction for Chronic Achilles Tendon Disorders. Tech. Foot Ankle Surg. 2017, 16, 117-123. [CrossRef]

22. Aicale, R.; Tarantino, D.; Via, A.G.; Oliva, F.; Maffulli, N. Z Shortening of Healed Achilles Tendon Rupture. In The Achilles Tendon: An Atlas of Surgical Procedures; Thermann, H., Becher, C., Carmont, M.R., Karlsson, J., Maffulli, N., Calder, J., van Dijk, C.N., Eds.; Springer: Berlin, Germany, 2017; pp. 125-128. [CrossRef]

23. Longo, U.G.; Petrillo, S.; Maffulli, N.; Denaro, V. Acute Achilles Tendon Rupture in Athletes. Foot Ankle Clin. 2013, 18, 319-338. [CrossRef]

24. Egger, A.C.; Berkowitz, M.J. Achilles tendon injuries. Curr. Rev. Musculoskelet. Med. 2017, 10, 72-80. [CrossRef] [PubMed]

25. Distefano, V.J.; Nixon, J.E. Achilles tendon rupture: Pathogenesis, diagnosis, and treatment by a modified pullout wire technique. J. Trauma 1972, 12, 671-677. [PubMed]

26. Bleakney, R.R.; Tallon, C.; Wong, J.K.; Lim, K.P.; Maffulli, N. Long-term Ultrasonographic Features of the Achilles Tendon After Rupture. Clin. J. Sport Med. 2002, 12, 273-278. [CrossRef] [PubMed]

27. Rolf, C.; Movin, T. Etiology, Histopathology, and Outcome of Surgery in Achillodynia. Foot Ankle Int. 1997, 18, 565-569. [CrossRef] [PubMed] 
28. Dams, O.C.; Reininga, I.H.; Gielen, J.L.; Akker-Scheek, I.V.D.; Zwerver, J. Imaging modalities in the diagnosis and monitoring of Achilles tendon ruptures: A systematic review. Injury 2017, 48, 2383-2399. [CrossRef] [PubMed]

29. Aicale, R.; Tarantino, D.; Maffulli, N. Basic Science of Tendons. In Bio-Orthopaedics: A New Approach; Gobbi, A., Espregueira-Mendes, J., Lane, J.G., Karahan, M., Eds.; Springer: Berlin, Germany, 2017; pp. $249-273$. [CrossRef]

30. Lin, T.W.T.W.; Cardenas, L.; Soslowsky, L.J.L.J. Biomechanics of tendon injury and repair. J. Biomech. 2004, 37, 865-877. [CrossRef] [PubMed]

31. Carmont, M.R.; Rossi, R.; Scheffler, S.; Mei-Dan, O.; Beaufils, P. Percutaneous \& Mini Invasive Achilles tendon repair. Sports Med. Arthrosc. Rehabil. Ther. Technol. 2011, 3, 28. [CrossRef]

32. Mark-Christensen, T.; Troelsen, A.; Kallemose, T.; Barfod, K.W. Functional rehabilitation of patients with acute Achilles tendon rupture: A meta-analysis of current evidence. Knee Surg. Sports Traumatol. Arthrosc. 2016, 24, 1852-1859. [CrossRef]

33. Caldwell, J.-M.E.; Vosseller, J.T. Maximizing Return to Sports after Achilles Tendon Rupture in Athletes. Foot Ankle Clin. 2019, 24, 439-445. [CrossRef]

34. Aström, M.; Westlin, N. Blood flow in chronic Achilles tendinopathy. Clin. Orthop. Relat. Res. 1994, 308, 166-172.

35. Karlsson, J.; Olsson, N.; Carmont, M.R.; Nilsson-Helander, K. Open Standard Technique. In The Achilles Tendon: An Atlas of Surgical Procedures; Thermann, H., Becher, C., Carmont, M.R., Karlsson, J., Maffulli, N., Calder, J., van Dijk, C.N., Eds.; Springer: Berlin, Germany, 2017; pp. 3-6.

36. Clain, M.R.; Baxter, D.E. Achilles Tendinitis. Foot Ankle 1992, 13, 482-487. [CrossRef] [PubMed]

37. Riggin, C.N.; Morris, T.R.; Soslowsky, L.J. Tendinopathy II: Etiology, Pathology, and Healing of Tendon Injury and Disease. In Tendon Degeneration: Understanding Tissue Physiology and Development to Engineer Functional Substitutes; Gomes, M.E., Reis, R.L., Rodrigues, M.T., Eds.; Elsevier: Amsterdam, The Netherlands, 2015; pp. 149-183.

38. Alsousou, J.; Keene, D.J.; Harrison, P.; Hulley, P.; Wagland, S.; Thompson, J.Y.; Parsons, S.R.; Byrne, C.; Schussel, M.M.; O'Connor, H.M.; et al. Platelet-rich plasma injection for adults with acute Achilles tendon rupture: The PATH-2 RCT. Effic. Mech. Eval. 2019, 6, 1-98. [CrossRef] [PubMed]

39. Kader, D.; Saxena, A.; Movin, T.; Maffulli, N. Achilles tendinopathy: Some aspects of basic science and clinical management. Br. J. Sports Med. 2002, 36, 239-249. [CrossRef] [PubMed]

40. Aicale, R.; Tarantino, D.; Maffulli, N. Overuse injuries in sport: A comprehensive overview. J. Orthop. Surg. Res. 2018, 13, 1-11. [CrossRef] [PubMed]

41. Maffulli, N.; Ewen, S.W.B.; Waterston, S.W.; Reaper, J.; Barrass, V. Tenocytes from Ruptured and Tendinopathic Achilles Tendons Produce Greater Quantities of Type III Collagen than Tenocytes from Normal Achilles Tendons: An in Vitro Model of Human Tendon Healing. Am. J. Sports Med. 2000, 28, 499-505. [CrossRef] [PubMed]

42. Maffulli, N.; Longo, U.G.; Maffulli, G.D.; Rabitti, C.; Khanna, A.; Denaro, V. Marked pathological changes proximal and distal to the site of rupture in acute Achilles tendon ruptures. Knee Surg. Sports Traumatol. Arthrosc. 2010, 19, 680-687. [CrossRef]

43. Inglis, A.E.; Sculco, T.P. Surgical repair of ruptures of the tendo Achillis. Clin. Orthop. Relat. Res. 1981, 156, 160-169. [CrossRef]

44. Myerson, M.S. Achilles Tendon Ruptures. Instr. Course Lect. 1999, 48, 219-230.

45. Dent, C.; Graham, G. Osteogenesis imperfecta and Achilles tendon rupture. Injury 1991, 22, $239-240$. [CrossRef]

46. Mathiak, G.; Wening, J.V.; Mathiak, M.; Neville, L.F.; Jungbluth, K.-H. Serum cholesterol is elevated in patients with Achilles tendon ruptures. Arch. Orthop. Trauma Surg. 1999, 119, 280-284. [CrossRef]

47. Ozgurtas, T.; Yildiz, C.; Serdar, M.; Atesalp, S.; Kutluay, T. Is High Concentration of Serum Lipids a Risk Factor for Achilles Tendon Rupture? Clin. Chim. Acta Int. J. Clin. Chem. 2003, 331, 25-28. [CrossRef]

48. Aicale, R.; Tarantino, D.; Maccauro, G.; Peretti, G.M.; Maffulli, N. Genetics in orthopaedic practice. J. Biol. Regul. Homeost. Agents 2019, 33 (Suppl. 1), 103-117. [PubMed]

49. Cramer, A.; Jacobsen, N.C.; Hansen, M.S.; Sandholdt, H.; Hölmich, P.; Barfod, K.W. Diabetes and treatment with orally administrated corticosteroids negatively affect treatment outcome at follow-up after acute Achilles tendon rupture. Knee Surg. Sports Traumatol. Arthrosc. 2020, 1-9. [CrossRef] [PubMed] 
50. Bisaccia, D.R.; Aicale, R.; Tarantino, D.; Peretti, G.M.; Maffulli, N. Biological and chemical changes in fluoroquinolone-associated tendinopathies: A systematic review. Br. Med. Bull. 2019, 130, 39-49. [CrossRef]

51. Holm, C.; Kjaer, M.; Eliasson, P. Achilles tendon rupture-Treatment and complications: A systematic review. Scand. J. Med. Sci. Sports 2015, 25, e1-e10. [CrossRef]

52. Westin, O.; Sjögren, T.; Svedman, S.; Horvath, A.; Senorski, E.H.; Samuelsson, K.; Ackermann, P. Treatment of acute Achilles tendon rupture-A multicentre, non-inferiority analysis. BMC Musculoskelet. Disord. 2020, 21, 1-10. [CrossRef]

53. Brumann, M.; Baumbach, S.F.; Mutschler, W.; Polzer, H. Accelerated rehabilitation following Achilles tendon repair after acute rupture-Development of an evidence-based treatment protocol. Injury 2014, 45, 1782-1790. [CrossRef]

54. Wang, K.C.; Cotter, E.J.; Cole, B.J.; Puzzitiello, R.N. Rehabilitation and Return to Play Following Achilles Tendon Repair. Oper. Tech. Sports Med. 2017, 25, 214-219. [CrossRef]

55. Carmont, M.R.; Silbernagel, K.G.; Edge, A.; Mei-Dan, O.; Karlsson, J.; Maffulli, N. Functional Outcome of Percutaneous Achilles Repair: Improvements in Achilles Tendon Total Rupture Score During the First Year. Orthop. J. Sports Med. 2013, 1. [CrossRef]

56. Metz, R.; Van Der Heijden, G.J.M.G.; Verleisdonk, E.-J.M.M.; Kolfschoten, N.; Verhofstad, M.H.J.; Van Der Werken, C. Effect of Complications After Minimally Invasive Surgical Repair of Acute Achilles Tendon Ruptures: Report on 211 Cases. Am. J. Sports Med. 2011, 39, 820-824. [CrossRef]

57. Trofa, D.P.; Miller, J.C.; Jang, E.S.; Woode, D.R.; Greisberg, J.K.; Vosseller, J.T. Professional Athletes' Return to Play and Performance After Operative Repair of an Achilles Tendon Rupture. Am. J. Sports Med. 2017, 45, 2864-2871. [CrossRef] [PubMed]

58. Fox, G.; Gabbe, B.J.; Richardson, M.; Oppy, A.; Page, R.S.; Edwards, E.; Hau, R.; Ekegren, C.L. Twelve-month outcomes following surgical repair of the Achilles tendon. Injury 2016, 47, 2370-2374. [CrossRef] [PubMed]

59. Lawrence, J.E.; Nasr, P.; Fountain, D.M.; Berman, L.; Robinson, A.H.N. Functional outcomes of conservatively managed acute ruptures of the Achilles tendon. Bone Jt. J. 2017, 99, 87-93. [CrossRef] [PubMed]

60. Claessen, F.M.A.P.; De Vos, R.-J.; Reijman, M.; Meuffels, D.E. Predictors of Primary Achilles Tendon Ruptures. Sports Med. 2014, 44, 1241-1259. [CrossRef] [PubMed]

61. Carmont, M.R.; Zellers, J.A.; Brorsson, A.; Olsson, N.; Nilsson-Helander, K.; Karlsson, J.; Silbernagel, K.G. Functional Outcomes of Achilles Tendon Minimally Invasive Repair Using 4- and 6-Strand Nonabsorbable Suture: A Cohort Comparison Study. Orthop. J. Sports Med. 2017, 5. [CrossRef]

62. Mubark, I.; Abouelela, A.; Arya, S.; Buchanan, D.; Elgalli, M.; Parker, J.; Ashwood, N.; Karagkevrekis, C. Achilles Tendon Rupture: Can the Tendon Gap on Ultrasound Scan Predict the Outcome of Functional Rehabilitation Program? Cureus 2020, 12, e10298. [CrossRef]

63. Yassin, M.; Myatt, R.; Thomas, W.; Gupta, V.; Hoque, T.; Mahadevan, D. Does size of tendon gap affect patient-reported outcome following Achilles tendon rupture treated with functional rehabilitation? Bone Jt. J. 2020, 102, 1535-1541. [CrossRef]

64. Braunstein, M.; Baumbach, S.F.; Boecker, W.; Carmont, M.R.; Polzer, H. Development of an accelerated functional rehabilitation protocol following minimal invasive Achilles tendon repair. Knee Surg. Sports Traumatol. Arthrosc. 2018, 26, 846-853. [CrossRef]

65. Oliva, F.; Rugiero, C.; Via, A.G.; Baldassarri, M.; Bernardi, G.; Biz, C.; Bossa, M.; Buda, R.; Buonocore, D.; Chianca, V.; et al. IS Mu. LT Achilles tendon ruptures guidelines. Muscle Ligaments Tendons J. 2018, 8, 310-363. [CrossRef]

66. Aufwerber, S.; Heijne, A.; Edman, G.; Silbernagel, K.G.; Ackermann, P.W. Does Early Functional Mobilization Affect Long-Term Outcomes After an Achilles Tendon Rupture? A Randomized Clinical Trial. Orthop. J. Sports Med. 2020, 8. [CrossRef]

67. Kim, U.; Choi, Y.S.; Jang, G.C.; Choi, Y.R. Early rehabilitation after open repair for patients with a rupture of the Achilles tendon. Injury 2017, 48, 1710-1713. [CrossRef] [PubMed]

68. Costa, M.; Achten, J.; Wagland, S.; Marian, I.R.; Maredza, M.; Schussel, M.M.; Liew, A.S.; Parsons, N.R.; Dutton, S.J.; Kearney, R.S.; et al. Plaster cast versus functional bracing for Achilles tendon rupture: The UKSTAR RCT. Health Technol. Assess. 2020, 24, 1-86. [CrossRef] [PubMed] 
69. Maempel, J.F.; Clement, N.D.; Duckworth, A.D.; Keenan, O.J.; White, T.O.; Biant, L.C. A Randomized Controlled Trial Comparing Traditional Plaster Cast Rehabilitation with Functional Walking Boot Rehabilitation for Acute Achilles Tendon Ruptures. Am. J. Sports Med. 2020, 48, 2755-2764. [CrossRef] [PubMed]

70. Hutchison, A.M.; Topliss, C.; Beard, D.; Evans, R.M.; Williams, P. The treatment of a rupture of the Achilles tendon using a dedicated management programme. Bone Jt. J. 2015, 97, 510-515. [CrossRef] [PubMed]

71. Aujla, R.S.; Patel, S.; Jones, A.; Bhatia, M. Non-operative functional treatment for acute Achilles tendon ruptures: The Leicester Achilles Management Protocol (LAMP). Injury 2019, 50, 995-999. [CrossRef]

72. Aufwerber, S.; Edman, G.; Silbernagel, K.G.; Ackermann, P.W. Changes in Tendon Elongation and Muscle Atrophy over Time after Achilles Tendon Rupture Repair: A Prospective Cohort Study on the Effects of Early Functional Mobilization. Am. J. Sports Med. 2020, 48, 3296-3305. [CrossRef]

73. Valkering, K.P.; Aufwerber, S.; Ranuccio, F.; Lunini, E.; Edman, G.; Ackermann, P.W. Functional weight-bearing mobilization after Achilles tendon rupture enhances early healing response: A single-blinded randomized controlled trial. Knee Surg. Sports Traumatol. Arthrosc. 2017, 25, 1807-1816. [CrossRef]

74. Touzell, A. The Achilles tendon: Management of acute and chronic conditions. Aust. J. Gen. Pract. 2020, 49, 715-719. [CrossRef]

75. Lim, C.S.; Lees, D.; Gwynne-Jones, D.P. Functional Outcome of Acute Achilles Tendon Rupture with and Without Operative Treatment Using Identical Functional Bracing Protocol. Foot Ankle Int. 2017, 38, 1331-1336. [CrossRef]

76. Harrington, T.L.; Breedlove, G.J.; Sharpe, J.J. Systematic Review of Nonoperative Functional Protocols for Acute Achilles Ruptures Utilizing a Formal Rehabilitation Protocol Showing Lowest Rerupture Rates. Foot Ankle Spec. 2020, 1938640020916954. [CrossRef]

77. Schepull, T.; Aspenberg, P. Early Controlled Tension Improves the Material Properties of Healing Human Achilles Tendons After Ruptures: A Randomized Trial. Am. J. Sports Med. 2013, 41, 2550-2557. [CrossRef]

78. Novacheck, T.F. Running injuries: A biomechanical approach. Instr. Course Lect. 1998, 47, 397-406.

79. Saleh, M.; Marshall, P.; Senior, R.; Macfarlane, A. The Sheffield splint for controlled early mobilisation after rupture of the calcaneal tendon. A prospective, randomised comparison with plaster treatment. J. Bone Jt. Surg. 1992, 74, 206-209. [CrossRef] [PubMed]

80. Mortensen, N.H.M.; Skov, O.; Jensen, P.E. Early Motion of the Ankle after Operative Treatment of a Rupture of the Achilles Tendon. A Prospective, Randomized Clinical and Radiographic Study. J. Bone Jt. Surg. 1999, 81, 983-990. [CrossRef] [PubMed]

81. Aspenberg, P. Stimulation of tendon repair: Mechanical loading, GDFs and platelets. A mini-review. Int. Orthop. 2007, 31, 783-789. [CrossRef] [PubMed]

82. Kjaer, M.; Langberg, H.; Miller, B.F.; Boushel, R.; Crameri, R.; Koskinen, S.; Heinemeier, K.; Olesen, J.L.; Døssing, S.; Hansen, M.; et al. Metabolic activity and collagen turnover in human tendon in response to physical activity. J. Musculoskelet. Neuronal Interact. 2005, 5, 41-52. [PubMed]

83. Palmes, D.; Spiegel, H.U.; Schneider, T.O.; Langer, M.; Stratmann, U.; Budny, T.; Probst, A. Achilles tendon healing: Long-term biomechanical effects of postoperative mobilization and immobilization in a new mouse model. J. Orthop. Res. 2002, 20, 939-946. [CrossRef]

84. Andersson, T.; Eliasson, P.; Aspenberg, P. Tissue memory in healing tendons: Short loading episodes stimulate healing. J. Appl. Physiol. 2009, 107, 417-421. [CrossRef]

85. Enwemeka, C.S.; Spielholz, I.N.; Nelson, A.J. The effect of early functional activities on experimentally tenotomized Achilles tendons in rats. Am. J. Phys. Med. Rehabil. 1988, 67, 264-269.

86. Krapf, D.; Kaipel, M.; Majewski, M. Structural and Biomechanical Characteristics After Early Mobilization in an Achilles Tendon Rupture Model: Operative versus Nonoperative Treatment. Orthopedics 2012, 35, e1383-e1388. [CrossRef]

87. Barfod, K.W.; Nielsen, E.G.; Olsen, B.H.; Vinicoff, P.G.; Troelsen, A.; Holmich, P. Risk of Deep Vein Thrombosis After Acute Achilles Tendon Rupture: A Secondary Analysis of a Randomized Controlled Trial Comparing Early Controlled Motion of the Ankle Versus Immobilization. Orthop. J. Sports Med. 2020, 8. [CrossRef] [PubMed]

88. Metz, R.; Verleisdonk, E.-J.M.M.; Van Der Heijden, G.J.-M.-G.; Clevers, G.-J.; Hammacher, E.R.; Verhofstad, M.H.J.; Van Der Werken, C. Acute Achilles Tendon Rupture: Minimally Invasive Surgery 
versus Nonoperative Treatment with Immediate Full Weightbearing-A Randomized Controlled Trial. Am. J. Sports Med. 2008, 36, 1688-1694. [CrossRef] [PubMed]

89. Kangas, J.; Pajala, A.; Siira, P.; Hämäläinen, M.; Leppilahti, J. Early Functional Treatment versus Early Immobilization in Tension of the Musculotendinous Unit after Achilles Rupture Repair: A Prospective, Randomized, Clinical Study. J. Trauma 2003, 54, 1171-1180. [CrossRef] [PubMed]

90. Kangas, J.; Pajala, A.; Ohtonen, P.; Leppilahti, J. Achilles Tendon Elongation after Rupture Repair: A Randomized Comparison of 2 Postoperative Regimens. Am. J. Sports Med. 2007, 35, 59-64. [CrossRef] [PubMed]

91. Suchak, A.A.; Bostick, G.P.; Beaupre, L.; Durand, D.C.; Jomha, N.M. The Influence of Early Weight-Bearing Compared with Non-Weight-Bearing After Surgical Repair of the Achilles Tendon. J. Bone Jt. Surg. 2008, 90, 1876-1883. [CrossRef]

92. Zhao, J.; Guo, W.; Zeng, X.; Kan, S. Research progress of early postoperative rehabilitation for acute Achilles tendon rupture after surgical repair. Chin. J. Reparative Reconstr. Surg. 2019, 33, 382-386.

93. Frankewycz, B.; Krutsch, W.; Weber, J.; Ernstberger, A.; Nerlich, M.; Pfeifer, C. Rehabilitation of Achilles tendon ruptures: Is early functional rehabilitation daily routine? Arch. Orthop. Trauma Surg. 2017, 137, 333-340. [CrossRef]

94. Maffulli, G.; Del Buono, A.; Richards, P.; Oliva, F.; Maffulli, N. Conservative, minimally invasive and open surgical repair for management of acute ruptures of the Achilles tendon: A clinical and functional retrospective study. Muscle Ligaments Tendons J. 2017, 7, 46-52. [CrossRef]

95. Ardern, C.L.; Glasgow, P.; Schneiders, A.; Witvrouw, E.; Clarsen, B.; Cools, A.; Gojanovic, B.; Griffin, S.; Khan, K.M.; Moksnes, H.; et al. 2016 Consensus statement on return to sport from the First World Congress in Sports Physical Therapy, Bern. Br. J. Sports Med. 2016, 50, 853-864. [CrossRef]

96. Holzgrefe, R.E.; McCarthy, T.P.; Wilson, J.M.; Bariteau, J.T.; Labib, S. Association of Strength Following Achilles Tendon Repair With Return to Same Level of Play in High-Level Athletes. Foot Ankle Int. 2020, 41, 1041-1048. [CrossRef]

97. Nilsson-Helander, K.; Thomeé, R.; Grävare-Silbernagel, K.; Thomeé, P.; Faxén, E.; Eriksson, B.I.; Karlsson, J. The Achilles Tendon Total Rupture Score (ATRS): Development and Validation. Am. J. Sports Med. 2007, 35, 421-426. [CrossRef] [PubMed]

98. Hansen, M.S.; Christensen, M.; Budolfsen, T.; Østergaard, T.F.; Kallemose, T.; Troelsen, A.; Barfod, K.W. Achilles tendon Total Rupture Score at 3 months can predict patients' ability to return to sport 1 year after injury. Knee Surg. Sports Traumatol. Arthrosc. 2016, 24, 1365-1371. [CrossRef] [PubMed]

99. Johns, W.; Walley, K.C.; Seedat, R.; Thordarson, D.B.; Jackson, B.; Gonzalez, T. Career Outlook and Performance of Professional Athletes after Achilles Tendon Rupture: A Systematic Review. Foot Ankle Int. 2020. [CrossRef] [PubMed]

100. Siu, R.; Ling, S.K.-K.; Fung, N.; Pak, N.; Yung, P.S. Prognosis of elite basketball players after an Achilles tendon rupture. Asia Pac. J. Sports Med. Arthrosc. Rehabil. Technol. 2020, 21, 5-10. [CrossRef]

101. Amin, N.H.; Old, A.B.; Tabb, L.P.; Garg, R.; Toossi, N.; Cerynik, D.L. Performance Outcomes After Repair of Complete Achilles Tendon Ruptures in National Basketball Association Players. Am. J. Sports Med. 2013, 41, 1864-1868. [CrossRef] [PubMed]

102. Trofa, D.P.; Noback, P.C.; Caldwell, J.-M.E.; Miller, J.C.; Greisberg, J.K.; Ahmad, C.S.; Vosseller, J.T. Professional Soccer Players' Return to Play and Performance After Operative Repair of Achilles Tendon Rupture. Orthop. J. Sports Med. 2018, 6. [CrossRef]

103. Lerch, T.D.; Schwinghammer, A.; Schmaranzer, F.; Anwander, H.; Ecker, T.M.; Schmid, T.; Weber, M.; Krause, F. Return to Sport and Patient Satisfaction at 5-Year Follow-up After Nonoperative Treatment for Acute Achilles Tendon Rupture. Foot Ankle Int. 2020, 41, 784-792. [CrossRef]

104. Grassi, A.; Rossi, G.; D’Hooghe, P.; Aujla, R.; Mosca, M.; Samuelsson, K.; Zaffagnini, S. Eighty-two per cent of male professional football (soccer) players return to play at the previous level two seasons after Achilles tendon rupture treated with surgical repair. Br. J. Sports Med. 2020, 54, 480-486. [CrossRef]

105. Ochen, Y.; Beks, R.B.; Van Heijl, M.; Hietbrink, F.; Leenen, L.P.H.; Van Der Velde, D.; Heng, M.; Van Der Meijden, O.; Groenwold, R.H.H.; Houwert, R.M. Operative treatment versus nonoperative treatment of Achilles tendon ruptures: Systematic review and meta-analysis. BMJ 2019, 364, k5120. [CrossRef]

106. Patel, K.A.; O'Malley, M.J. Management of Achilles Tendon Injuries in the Elite Athlete. Orthop. Clin. North Am. 2020, 51, 533-539. [CrossRef] 
107. Lu, J.; Liang, X.; Ma, Q. Early Functional Rehabilitation for Acute Achilles Tendon Ruptures: An Update Meta-Analysis of Randomized Controlled Trials. J. Foot Ankle Surg. 2019, 58, 938-945. [CrossRef] [PubMed]

108. Senorski, E.H.; Svedman, S.; Svantesson, E.; Danielsson, A.; Krupic, F.; Ackermann, P.; Westin, O. Understanding limitations in sport 1 year after an Achilles tendon rupture: A multicentre analysis of 285 patients. Knee Surg. Sports Traumatol. Arthrosc. 2020, 28, 233-244. [CrossRef] [PubMed]

109. Wise, P.M.; King, J.L.; Stauch, C.M.; Walley, K.C.; Aynardi, M.C.; Gallo, R.A. Outcomes of NCAA Defensive Football Players Following Achilles Tendon Repair. Foot Ankle Int. 2020, 41, 398-402. [CrossRef] [PubMed]

Publisher's Note: MDPI stays neutral with regard to jurisdictional claims in published maps and institutional affiliations.

(C) 2020 by the authors. Licensee MDPI, Basel, Switzerland. This article is an open access article distributed under the terms and conditions of the Creative Commons Attribution (CC BY) license (http://creativecommons.org/licenses/by/4.0/). 